\title{
Head Teachers' Characteristics and Instructional Leadership in Curriculum Implementation in Secondary Schools, Siaya County, Kenya
}

\author{
Ursulla Achieng Okoth \\ Senior Lecturer, Department of Educational Administration and Planning \\ University of Nairobi, Kenya
}

Doi:10.19044/esj.2018.v14n19p75 URL:http://dx.doi.org/10.19044/esj.2018.v14n19p75

\begin{abstract}
Personal or background characteristics can influence head teachers instructional leadership in schools. This study investigated the relationship, if any, between the head teacher's instructional leadership and the head teacher's background variables such as education/ professional qualification, gender, age, $p$ and teaching experience in the implementation of curriculum (Environmental Education) in secondary schools. Thirty headteachers and 183 teachers randomly sampled participated. Questionnaire was used to collect data in the survey. Findings: The Instructional Leadership Mean Score for mostvariables was moderate,Instructional Leadership Mean Score was independent of head teacher characteristics such as sex, age, and teaching experience but dependent on head teacher qualification. Recommendation: Quality Assurance and Standards officers need to monitor instructions in schools regularly to assist heads, Training of headteacherson instructional leadership should be ongoing and be ensured byboth Teachers Service Commission and Kenya Education Management Institute.
\end{abstract}

Keywords: Instructional leadership, headteachers' characteristics,curriculum implementation (Environmental Education), secondary schools, Kenya

\section{Introduction}

Leadership is an influence relationship among leaders and followers who intend real changes that reflect their shared purposes (Daft, 2008, Daft and Marcic 2006). Instructional leadership refers to the actions that a head teacher takes or delegates to teachers and others to enhance student learning. The personal attributes of the head teacher also help to bring out the instructional leadership (Prokopenko, 1998;Okoth, 2008). The instructional leadership is applied in supervision andmonitoring curriculum implementation. This improves quality of education and enhances academic 
achievement of students. Through leadership, the headteacher provides resources and sets the pace for academic performance (Edmonds, 1979; Leithwood \& Jantzi (2000). The leader gives a clear vision and encourages staff and students to work hard. In addition they guide teachers on what should be done and how; and always monitor professional records such as Schemes of work, Lesson plans, Weekly records of work, Progress records and examination analysis records (MoE, 2000). The head teachers require professional training in order to maintain leadership role. Background characteristics have been linked to instructional leadership (Okumbe, 2007; Okoth, 2000; 2008; Daft, 2008).

\section{Litrature Review}

This study applied perception of teachers on various leadership role variables. According to Huczynski and Buchanan (2001), perception is the dynamic psychological process responsible for attempting to organize and interpret sensory data. Teachers process and interpret the incoming raw data concerning the head teachers in the light of past experiences, in terms of current needs and interests, in terms of their knowledge, expectations, beliefs and motives. Heider (1958) and Kelley (1971) argue that our understanding of our social world is based on our continual attempts to do casual analysis based on how we interpret our experience. This allows prediction and control of certain future social events (in Huczynski and Buchanan, 2001). In perception, the proximity principle assumes that things are grouped together if they appear similar and the principle of closure enables the mind to fill in gaps from what is known from past experience.

Headteachers plan, organise, co-ordinate and control instructional programmes. Therefore, instructional leadership functions include setting academic standards, providing incentives for learning, and providing incentives to teachers. Head teachers encourage decision participation; assess teaching performance, academic quality of student input, relations with teachers and community, andsupport systems including guidance and counselling. They promote teachers' sense of efficacy, professional development, and instructional improvement. The head teacher's instructional leadership in curriculum implementation can go a long way in ensuring students gain knowledge for enhancing quality education.

The Ministry of Education advocates that teachers should attain high academic level and be trained as professionals in areas such as educational psychology, sociology, philosophy, curriculum development, and administration, and also in subject content and methodology. Ministry of Education in Kenya is also concerned about certification and licensing of teachers from Diploma Teacher Training Colleges and the Universities. Quality Assurance and Standards (QAS) officersassess the Diploma students 
on Teaching Practice and the currentdiploma students are examined by Kenya National Examinations Council (KNEC), a move aimed to standardise teacher education in private Diploma Colleges. Directorate of QAS (2006) gives guidelines relating to proficiency in the teaching profession. Several instructional leadership variables such as giving vision, encouraging hardwork, checking professional records, analysis of results and monitoring curriculum among others were considered.

Gender or sex of the individual has been shown to influence leadership and the way leadership is perceived. According to Daft (2008) female managers were rated higher by subordinates on interpersonal skills as well as on factors such as task behaviour, communication, and the ability to motivate others. Male leaders tend to be competitive and individualistic.

The age factor is important in school administration as it influences authority and the experiences of the head teacher (Mbiti, 2007). Older people may respect people of their age than youngerones. The Age is important in planning functions of the Ministry of Education and is a major determinant of how curriculum is offered in educational institutions.

Available literature indicates a strong relationship between student examination outcome and the teacher's years of teaching experience (National Centre for Education Statistics (NCES), 2000; Rowan, Correnti and Miller, 2002). Teachers with few years of experience, usually three years and below are less effective compared to those of more years of experience. However, beyond five years of teaching experience the influence decreases. This may suggest that experience of ten years may not have significant difference in performance when compared with the counterpart with five years teaching experience (Darling-Hammond, 2000). The teachers' experience in years may determine their effectiveness in the implementation of curriculumin secondary schools.

\section{Research Questions} leadership?

1. What is the perception of teachers on head teachers' instructional

2. What is the relationship between the head teachers' instructional leadership and the background variables such as education /professional qualification gender, age, and teaching experience in the implementation of curriculum (Environmental Education) in secondary schools in Siaya county, Kenya?

Null Hypothesis: There is no significant relationship between instructional leadership mean score and the background characteristics of the head teachers such as qualification, sex, age, and teaching experience in years. 


\section{Methodology}

Sampling:Stratified sampling method was used to pick 30 schools such that sizes, gender, type (boarding or day) were all considered. A simple random probability method was used to select proportionately the number of required schools per stratumwhile the 30 heads became respondents automatically. A total of 183 teachers were selected by random sampling.

Reliability of instrument: A questionnaire was used to collect data and the computed co-efficient value of 0.7 for teachers' questionnaire was above 0.6, indicated that the instrument was reliable for use (Mugenda, 2008).

Data analysis: Descriptive statistics and Chi-square test were used to analyse data. The probability value of 0.05 was used to accept or reject the Null hypothesis (Kothari, 2008).

\section{Findings}

\subsection{Teachers' Perceptionson instructional leadership of school heads}

Table 1 presents head teachers'instructional leadership ratingas perceived by teachers on instructional leadership items and the mean for each item.

Table 1 Teachers' Rating of Head Teachers' Instructional Leadership

\begin{tabular}{|c|c|c|c|c|c|c|c|c|c|c|c|c|}
\hline \multirow[b]{2}{*}{ The Head teacher } & \multicolumn{2}{|c|}{$\begin{array}{c}\text { No } \\
\text { opinion }\end{array}$} & \multicolumn{2}{|c|}{$\begin{array}{l}\text { Strongly } \\
\text { disagree }\end{array}$} & \multicolumn{2}{|c|}{ Disagree } & \multicolumn{2}{|c|}{ Agree } & \multicolumn{2}{|c|}{$\begin{array}{l}\text { Strongly } \\
\text { Agree }\end{array}$} & \multicolumn{2}{|c|}{ Mean } \\
\hline & $\mathrm{f}$ & $\%$ & $\mathrm{f}$ & $\%$ & $\mathrm{f}$ & $\%$ & $\mathrm{~F}$ & $\%$ & $\mathrm{~F}$ & $\%$ & $\mathrm{n}$ & mean \\
\hline Is a Role model & 11 & 6.0 & 11 & 6.0 & 7 & 3.8 & 71 & 39.0 & 83 & 45.3 & 183 & 4.11 \\
\hline $\begin{array}{l}\text { Has talent and ability to } \\
\text { cope with decision making }\end{array}$ & 11 & 6.0 & 3 & 1.8 & 6 & 3.3 & 94 & 52.5 & 67 & 36.6 & 183 & 4.12 \\
\hline Presents new challenges & 30 & 16.4 & 8 & 4.4 & 12 & 6.6 & 87 & 45.5 & 46 & 25.6 & 183 & 3.61 \\
\hline $\begin{array}{c}\text { Believes in teacher ability to } \\
\text { meet obstacles }\end{array}$ & 11 & 6.0 & 7 & 3.8 & 11 & 6.0 & 79 & 43.2 & 75 & 41.0 & 183 & 4.09 \\
\hline $\begin{array}{l}\text { Strives collective goal of } \\
\text { fulfilling a vision }\end{array}$ & 20 & 10.9 & 5 & 2.7 & 7 & 3.8 & 72 & 39.4 & 79 & 43.2 & 183 & 4.01 \\
\hline $\begin{array}{c}\text { Has positive EE presence in } \\
\text { the school }\end{array}$ & 32 & 17.5 & 9 & 4.9 & 18 & 9.8 & 66 & 36.1 & 58 & 31.7 & 183 & 3.6 \\
\hline $\begin{array}{c}\text { Visible in school checking } \\
\text { EE }\end{array}$ & 31 & 16.9 & 13 & 7.1 & 23 & 12.5 & 65 & 35.5 & 51 & 27.9 & 183 & 3.5 \\
\hline $\begin{array}{l}\text { Encourages students to work } \\
\text { hard in EE }\end{array}$ & 34 & 18.6 & 9 & 4.9 & 15 & 8.2 & 59 & 32.2 & 66 & 36.1 & 183 & 3.62 \\
\hline Checks on EE assignments & 32 & 17.5 & 9 & 4.9 & 27 & 14.8 & 74 & 40.4 & 41 & 22.4 & 183 & 3.45 \\
\hline $\begin{array}{c}\text { Regularly observes classes } \\
\text { for EE }\end{array}$ & 47 & 25.7 & 14 & 7.7 & 26 & 14.2 & 60 & 32.8 & 36 & 19.7 & 183 & 3.13 \\
\hline $\begin{array}{l}\text { Gives teachers autonomy in } \\
\text { making decisions about } \\
\text { implementing EE }\end{array}$ & 40 & 21.9 & 14 & 7.7 & 20 & 10.9 & 77 & 42.1 & 32 & 17.5 & 183 & 3.26 \\
\hline $\begin{array}{c}\text { Encourages staff } \\
\text { participation in EE projects }\end{array}$ & 40 & 21.9 & 14 & 7.7 & 18 & 9.8 & 71 & 38.8 & 40 & 21.9 & 183 & 3.31 \\
\hline $\begin{array}{l}\text { Regularly checks on } \\
\text { schemes and records }\end{array}$ & 16 & 8.7 & 9 & 4.9 & 18 & 9.9 & 67 & 36.6 & 73 & 39.9 & 183 & 3.94 \\
\hline Checks lesson plans & 36 & 19.7 & 23 & 12.6 & 25 & 13.6 & 55 & 30.1 & 44 & 24.0 & 183 & 3.27 \\
\hline $\begin{array}{l}\text { Monitors implementation of } \\
\text { EE }\end{array}$ & 16 & 8.7 & 8 & 4.4 & 13 & 7.1 & 70 & 38.3 & 76 & 41.5 & 183 & 3.99 \\
\hline
\end{tabular}




\begin{tabular}{|c|c|c|c|c|c|c|c|c|c|c|c|c|}
\hline $\begin{array}{l}\text { Provides funds for teaching } \\
\text { aids for EE }\end{array}$ & 21 & 11.5 & 13 & 7.1 & 16 & 8.7 & 58 & 31.7 & 75 & 41.0 & 183 & 3.84 \\
\hline $\begin{array}{l}\text { Analyses results for } \\
\text { improvement of EE }\end{array}$ & 13 & 7.1 & 10 & 5.5 & 16 & 8.7 & 55 & 30.1 & 89 & 48.6 & 183 & 4.08 \\
\hline $\begin{array}{l}\text { Organizes meetings with } \\
\text { other schools for EE }\end{array}$ & 17 & 9.3 & 14 & 7.7 & 18 & 9.8 & 52 & 28.4 & 82 & 44.8 & 183 & 3.93 \\
\hline
\end{tabular}

The results on whether the head teacher is a role model in the school for the teachers and students to emulate showed that most of the teachers 45.3 percentstrongly agree and 39 percent agree the head teachers acted as role models. However, 6.0 percent teachers strongly disagree and 3.8 percent disagree that head teachers act as role models while 6.0 percent had no opinion. Authentic leaders build their practice outward from their core commitment making them role models for enhancing environmental education.

The talent and ability of the head teacher to cope with decision making was rated as agree 52.5 percent and strongly agree 36.6 percent, and no opinion 6.0 percent, The data illustrates that majority of the head teachers are capable of making decisions regarding Environmental Education but there is room for improvement for 4.4 percent who disagree, 1.8 percent who strongly disagree, and 6 percent who had no opinion.

The ability of the head teacher to present new challenges and projects in Environmental Education was rated by 45.5 percentagree, followed by 25.6 percent strongly agree. The rest 16.4 percent teachers had no opinion, 6.6 percent disagree, and 4.4 percent strongly disagree.

The data on whether head teachers believe in teachers' ability to deal with obstacles in Environmental Education showed that 41 percent said they strongly agreed, and 43.2 percent agreed. The rest, 6.0 percent disagreed and 3.8 percent strongly agreed head teachers believed in teachers' ability to deal with obstacles. Another 6.0 percent had no opinion. Head teachers can empower teachers through seminars.

The data shows as a leader, head teachers strive towards the collective goal of fulfilling a vision. Strongly agree comprised 43.2 percent teachers, agree 38.4 percent, no opinion 10.9 percent, disagree 3.8 percent, and the least 2.7 percent teachers strongly disagree the head teacher strives towards a collective goal. Head teachers can improve in skills required to meet a collective goal.

The teachers were asked if the head teachers' presence in the school was important. The results showed the highest proportion of teachers 36.1 percent said they agree, 31.7 percent strongly agree, 17.5 percent had no opinion, 9.8 percent disagree 4.9 percent strongly disagree. The results indicate 67.8 percent teachers perceive that the presence of the head teacher in school is important. Mbiti (2007) concurs that the head teacher's presence in school is significant. The results imply that head teachers need to be seen in the school. 
The data on whether the head teacher was visible within the school checking Environmental Education showed 12.5 percent teachers disagree, and 7.1 percent teachers strongly disagreed that the head teachers checked on environmental education. Nevertheless, 35.5 percent strongly agree and 27.9 percentagree the head teachers do check. The remaining 16.9 percent teachers had no opinion. The head teachers should be visible checking on environmental education in particular.

The results on whether the head teachers encourage students to work hard in Environmental Education showed that 36.1 percent strongly agree and 32.2 percentagree. 8.2 percent disagree, 4.9 percent strongly disagree head teachers encourage their students while 18.6 percent had no opinion. The results suggest that head teachers need to encourage students more in areas concerning environment.

In response to the question whether head teachers check on Environmental Education assignments and projects the results showed that the highest proportion of teachers 40.4 percent agree, 22.4 percent strongly agree, 17.5 percent no opinion, 14.8 percent disagree and 4.9 percent strongly disagree. More emphasis should be laid on checking assignments and projects since students' learning is enhanced through personal involvement.

The results on whether the head teacher regularly observes classes for Environmental Education showed that 25.7 percent of the teachers had no opinion. The highest proportion 32.8 percent agreed and 19.7 percent strongly agreed the head teachers monitor the teaching of Environmental Education. However, 14.2 percent disagree and 7.7 percent strongly disagree implying the head teachers do not observe lessons to check for Environmental Education. Physical presence in classrooms to monitor classroom activities has been cited as a key way of discovering factors that impede learning of Environmental Education and set out to correct them. As a supervisor, the head teacher is likely to get information about teaching aids and methods of teaching used in lessons (Wafula, 2007).

Teachers were asked if they have autonomy to make decisions about implementing environmental education. The data in Table 1 shows 42.1 percent teachers agreed and 17.5 percent strongly agreed that the head teacher gives autonomy. Meanwhile, 10.9 percent disagree, 7.7 percent strongly disagree, and 21.9 percent of the teachers had no opinion whether they had autonomy to make decisions. Head teachers require some training to help them on how to use others in decision making and in particular teachers.

The results on whether the head teachers encourage staff participation in Environmental Education projects showed the highest proportions of teachers 38.8 percent agree and 21.9 percent strongly agree head teachers encourage staff participation in environmental education projects. 21.9 percent of the teachers had no opinion, 9.8 percent disagreed and 7.7 percent strongly 
disagreed that head teachers encourage participation in projects concerned with the environment. The encouragement by the head teacher is important in order to increase awareness in environmental education.

According to the data on whether the head teacher provided funds for buying teaching aids, 31.7 percent agree and 41.0 percent of the teachers strongly agree head teachers provide funds for buying teaching aids for Environmental Education. 11.5 percent had no opinion, 8.7 percent disagree, and 7.1 percent strongly disagree that head teachers provide funds. The head teachers need to look for more funding from parents or the government.

In response to whether the head teacher analyses results for improvement of Environmental Education 8.7 percent disagree and 5.5 percent strongly disagree the head teachers analyse results. Nevertheless, 48.6 percent teachers strongly agree and 30.1 percentagree the head teacher analyses results while 7.1 percent teachers had no opinion the head teacher analyses results to enhance performance in environmental education.

Teachers were asked whether the head teacher organizes meetings with other schools for Environmental Education. The results show 9.3 percent of the teachers had no opinion, 44.8 percent teachers strongly agree and 28.4 percentagree that head teachers organise meetings with other schools. This could be in view of joint mock examinations previously done in the districts as well as sports. However, 9.8 percent teachers disagree and 7.7 percent strongly disagree that head teachers ever organise meetings with other schools. Checkly (2000) commends such meetings for the improvement of the working culture in the schools. Head teachers need to facilitate more meetings in which ideas can be shared in order to improve the implementation of Environmental education.

Supervision role such as regular checking of the records of work, schemes of work, lesson plans, and classroom visits may reveal to the head teacher the extent to which participatory methods are in use. Schemes of work show the breakdown of work to be covered in a term while records of work show topics covered weekly.

The data on responses to head teachers regularly checking schemes and records of work shows most teachers 39.9 percent strongly agree, followed by 36.6 percent agree, 9.9 percent disagree, 8.7 percent had no opinion, and 4.9 percent strongly disagree. Although many head teachers check on the records, there is a high percentage of teachers, 23.5 percent that have rated the head teachers unfavourably (no opinion and disagree).

A lesson plan shows in summary the content, resources, and teaching method a teacher intends to use in a lesson. Data on whether head teachers check lesson plans show that a high proportion of teachers, 30.1 percentagree they check, followed by 24.0 percent strongly agree, 19.7 percent had no opinion, 13.6 percent disagree, and 12.6 strongly disagree. Although some 
head teachers check on the lesson plans, there is a high percentage that does not check. Wafula (2007) found that in reality fewer head teachers actually checked schemes of work, records of work, lesson plans, and student notes instead, the deputy head teachers performed some of these functions. There is need to check if lesson plans are regularly prepared by teachers and checked by the head teacher. Kenya Institute of Curriculum Development (KICD) Officers rated the head teachers as 'average' in checking schemes of work while Quality Assurance and Standards officer felt that more effort was expected from the head teachers.

Monitoring refers to the regular checks carried out to ensure effective implementation of curriculum (environmental education). The findings show that most, 41.5 percent teachers strongly agree head teachers monitor implementation of Environmental Education, 38.3 percentagree, 8.7 percent had no opinion, 7.1 percent disagree, and 4.4 percent strongly disagree.

When asked whether QAS monitored the implementation of Environmental Education, the officers from District Education Office (DEO), QAS and KICD responded that Directorate of Quality Assurance and Standards' efforts were below average. The practice of monitoring is recommended to ensure effectiveness therefore QAS should emphasise Environmental Education in routine supervision.

\subsubsection{Mean performance of each item}

Amajority of the items 70 percent had a mean of 3-3.9 meaning rating was average while 30 percent had a mean between 4-5 (Talented and ability to make decision- 4.12, Role model-4.11, Head teacher believes in teacher ability4.09, Analyses results for improvement of EE- 4.08, Head teacher strives collective goal of fulfilling a vision- 4.01). The results show that head teachers did not exert maximum effort in any of the items.

\subsubsection{Computing Mean Instructional Leadership Score}

The teachers responded to eighteen items on instructional leadership. Each item had a response on a Likert Scale ranging from strongly agree to strongly disagree. The total perception score per respondent in the 18 items was calculated to give the head teachers' Instructional Leadership Score. The scores were averaged per school in order to obtain a single mean score referred to as the Instructional Leadership Mean Score (ILMS) which is the basis for other statistical tests. The teachers' mean ratings of head teachers Instructional Leadership roles were grouped into five as shown below: 


\begin{tabular}{lll}
\hline Score Group & Mean & Interpretation \\
\hline 90 and above & 5 & Strongly Agree \\
$72-89$ & 4 & Agree \\
$54-71$ & 3 & Disagree \\
$36-53$ & 2 & Strongly Disagree \\
$18-35$ & 1 & No Opinion \\
\hline
\end{tabular}

Assuming the head teacher scored a maximum of 5 (Strongly Agree) for each of the eighteen items the candidate would score 90 and the least scoring 1 (No Opinion) would obtain 18. Likewise a score of 2 would lead to 36 , a score of 3 lead to 54 , and a score of 4 lead to 64 .

The results show that majority, 20 (66.7 percent) of the head teachers scored between 3 and 3.9, while 9 (30 percent) scored between 4 and 5 and 1 (3.3 percent) below 3 out of a maximum of five (see Appendix A).

\subsection{Hypothesis testing}

$\mathrm{H}_{\mathrm{o}}$ There is no significant relationshipbetween instructional leadership mean score and the background characteristics of the head teachers such as qualification, sex, age, and teaching experience in years.

\subsubsection{Academic and Professional Qualifications of Head Teachers}

Qualification of teachers is a major concern for effective curriculum implementation and is shown in Table 2.

Table 2 Distribution of Head-teachers by Professional Qualification

\begin{tabular}{ccc}
\hline Academic and & \multicolumn{2}{c}{ Head teachers } \\
Professional Qualification & Frequency & Percent \\
\hline Diploma & 6 & 20.0 \\
BA/BSc* & 1 & 3.3 \\
BA/BSc with PGDE & 2 & 6.7 \\
B.ED & 21 & 70.0 \\
\hline Total & $\mathbf{3 0}$ & $\mathbf{1 0 0 . 0}$ \\
\hline \multicolumn{2}{c}{$*$ Non professional }
\end{tabular}

Table 2 shows that 70.0 percent of the head teachers are holders of Bachelor of Education degree, 20.0 percent Diploma, 6.7 percent Bachelor of Arts (BA) or Bachelor of Science (BSc) with Post Graduate Diploma in Education (PGDE), and only 3.3 percent hold a non-teaching professional certificate (BA or BSc). The head teacher's instructional leadership was dependent on qualification, the variables were found to be dependent.

The results show 3.3 percent of the head teachers were not professional teachers due to lack of training in education. The low percentage of non professional teachers shows the commitment of TSC to engage professionally qualified teachers who are competent to teach in the schools. The results also imply that TSC is increasingly engaging professional teachers to head secondary schools 


\section{Testing Hypothesis 1}

i) Ho1: There is no significant relationship between the head teachers' Instructional Leadership Mean Score (ILMS) and the head teachers' educational qualification.

Chi-square test $\left(\chi^{2}\right)$ was used to determine the independence of the two variables. The result gave p-values of Pearson Chi test square 0.035 and Likelihood ratio 0.512. The result shows we reject the Null Hypothesis because the p-value is less than 0.05 for the Chi-test. This means the two variables are dependent such that qualification influences instructional leadership.Professional Qualification is significant because headteachers need to be grounded in all aspects of education such as psychology, guidance and counselling, administration and curriculum development. In addition, they need to be adequate in subject content which comes with training.

\subsubsection{Sex of Head teachers}

Head teachers were asked to state their sexand the results are discussed. It was observed that the majority, 70.0 percentof the head teachers who participated in the survey were males representing more than half while female head teachers were 30.0 percent.

\section{Testing Hypothesis 2}

ii) $H_{02}$ : There is no significant relationship between the head teachers' Instructional Leadership Mean Score and the head teachers' sex.

The Chi square test $\left(\chi^{2}\right)$ was used to test significance of the relationship between Instructional Leadership Mean Score and sex of the head teacher. The p-values of Pearson chi-square 0.582 and likelihood ratio 0.342 are greater than 0.05. As a result we fail to reject the Null Hypothesis that Instructional Leadership Mean Score and sex are independent. The gender of head teacher does not influence instructional leadership.

\subsubsection{Age of Head teachers}

The head teachers'responses on their age bracket are presented in Table 3.

Table 3 Distribution of Head Teachers by Age

\begin{tabular}{lcc}
\hline Age bracket & Frequency & Percent \\
\hline Below 25 years & 0 & 0.0 \\
25-34 years & 2 & 6.7 \\
35-44 years & 15 & 50.0 \\
45-54 years & 12 & 40.0 \\
$\quad$ 55 years and above & 1 & 3.3 \\
\hline Total & $\mathbf{3 0}$ & $\mathbf{1 0 0 . 0}$ \\
\hline
\end{tabular}


The results indicated that majority of the head teachers, 50.0 percent, were between $35-44$ years age bracket, followed by 40.0 percent from the age group 45-54 years (90\%), 6.7 percent were in the age bracket 25-34 years and only 3.3 percent in the age bracket 55 years and above.

The age of the head teachers who were selected to participate in the study ranged between 25-55 years which represents an active and experienced segment of the secondary school teaching force capable of implementing curriculum. Employees of TSC attain retirement age at 60 years.

\section{Testing Hypothesis 3}

iv)Ho 3: There is no significant relationship between the teachers' instructional leadership mean score and the head teachers' age.

Chi-squaretest result for independence of age and Instructional Leadership Mean Score gives p-value of Pearson's chi-test of 0.378 and Likelihood ratio of 0.632 both results being higher than 0.05 . We fail to reject the Null Hypothesis that the two are independent. This suggests the two variables are independent.

\subsubsection{Teaching Experience of Head-teachers}

The head teachers were asked to indicate their teaching experience.This is presented inTable 4 which shows the teaching experience in years.

Table 4 Distribution of Head-teachers by Teaching Experience in Years

\begin{tabular}{lcc}
\hline Teaching experience in & \multicolumn{2}{c}{ Head teachers } \\
years & Frequency & Percent \\
\hline 1-5 years & 1 & 3.3 \\
6-10 years & 3 & 10.0 \\
11-15 years & 5 & 16.7 \\
16-20 years & 11 & 36.7 \\
21-25 years & 7 & 23.3 \\
26-30 years & 3 & 10.0 \\
\hline Total & $\mathbf{3 0}$ & $\mathbf{1 0 0 . 0}$ \\
\hline
\end{tabular}

The results indicate many head teachers had long teaching experience of which 36.7 percent had taught for 16-20 years, 23.3 percent for 21-25 years, and 16.7 percent for 11-15 years. The experience could be used to enhance teacher participation in curriculum implementation. TSC does not engage new graduates in school leadership position shown by 3.3 percent for $0-5$ year bracket and none from below one year. 


\section{Testing hypothesis 4}

iv) Ho 4:There is no significant relationship between the head teachers' Instructional Leadership Mean Score and the head teachers' teaching experience.

Chi-square test was used to test the significance of the relationship between the Instructional Leadership Mean Score and years of experience as a head of a school. The p-values of Pearson's chi-test 0.523 and Likelihood ratio 0.73 which are greater than 0.05 mean we fail to reject the Null Hypothesis that years of experience and Instructional Leadership Mean Score are independent of each other. The two are independent.

\subsubsection{Head Teachers' Experience as Head of School}

As opposed to the number of years the head teacher has been teaching, the years the head teacher has been in leadership position is important. The experience could improve decision-making. The findings show that most of the head teachers who participated in the survey are experienced teachers who can implement school curriculum. A proportion of 46.7 percent had worked as head teachers for a period between 6-10 years and 13.3 percent had worked for a period between 16-20 years making a total of 60 percent. The year bracket $1-5$ years had 33.3 percent while $11-15$ years and 20 years and above had only 3.3 percent each.

The years a teacher served as an ordinary teacher and those served as a head teacher were cross tabulated and the results presented in Table 5.

Table 5:Relation Between Headteachers' Teaching years and Experience as school $\operatorname{head}(\mathrm{n}=183)$

\begin{tabular}{|c|c|c|c|c|c|c|c|c|}
\hline \multirow{2}{*}{\multicolumn{2}{|c|}{$\begin{array}{c}\text { Experience as Head } \\
\text { teacher }\end{array}$}} & \multicolumn{6}{|c|}{ Teaching experience in Years (yrs) } & \multirow[b]{2}{*}{ Total } \\
\hline & & \multirow{2}{*}{$\frac{0-5}{1}$} & \multirow{2}{*}{$\frac{6-10}{2}$} & \multirow{2}{*}{$\frac{11-15}{2}$} & \multirow{2}{*}{$\frac{16-20}{4}$} & \multirow{2}{*}{$\frac{\mathbf{2 0 - 2 5}}{1}$} & \multirow{2}{*}{$\begin{array}{l}\mathbf{2 5 - 3 0} \\
0\end{array}$} & \\
\hline $1-5 y r s$ & $\mathrm{f}$ & & & & & & & 10 \\
\hline & $\%$ & 3.3 & 6.7 & 6.7 & 13.3 & 3.3 & 0.0 & 33.3 \\
\hline 6-10yrs & $\mathrm{f}$ & 0 & 1 & 3 & 5 & 4 & 1 & 14 \\
\hline & $\%$ & 0.0 & 3.3 & 10.0 & 16.7 & 13.3 & 3.3 & 46.7 \\
\hline $11-15 y r s$ & $\mathrm{f}$ & 0 & 0 & 0 & 1 & 0 & 0 & 1.0 \\
\hline & $\%$ & 0.0 & 0.0 & 0.0 & 3.3 & 0.0 & 0.0 & 3.3 \\
\hline $16-20 y r s$ & $\mathrm{f}$ & 0 & 1 & 0 & 0 & 2 & 1 & 4.0 \\
\hline & $\%$ & 0.0 & 3.3 & 0.0 & 0.0 & 6.7 & 3.3 & 13.3 \\
\hline 20yrs and above & $\mathrm{f}$ & 0.0 & 0 & 0 & 0 & 0 & 1 & 1 \\
\hline & $\%$ & 0.0 & 0.0 & 0.0 & 0.0 & 0.0 & 3.3 & 3.3 \\
\hline Total & $\begin{array}{l}\mathbf{f} \\
\%\end{array}$ & $\begin{array}{l}1 \\
3.3\end{array}$ & $\begin{array}{c}4 \\
13.3\end{array}$ & $\begin{array}{c}5 \\
16.7\end{array}$ & $\begin{array}{l}10 \\
33.3\end{array}$ & $\begin{array}{c}7 \\
23.3\end{array}$ & $\begin{array}{l}3 \\
10.0\end{array}$ & $\begin{array}{l}30 \\
100.0\end{array}$ \\
\hline
\end{tabular}

The results show that teachers who had served longer had a higher chance of being appointed to head teacher position. It can be argued that experience increases their chances of promotion to headship after rising through the job group ranks over the years. Further assumption is that experience may increase 
awareness of teachers in environment issues and increase the chances of their implementation.

\section{Conclusion}

i.Head teachers scored moderately 3-3.9 on most instructional leadership items.

ii. Instructional Leadership Mean Score was independent of head teacher characteristics such as sex, age, and teaching experience, Instructional leadership was found to be dependent on professional qualification.

\section{Recommendation}

Quality Assurance and Standards officers need to monitor instructions in schools regularly to assist heads, Training of headteacherson instructional leadership should be ongoing and be ensured by both Teachers Service Commission and Kenya Education Management Institute. Kenya Education Management Institute should review curriculum for training head teachers in instructional leadership or supervision.

\section{References:}

1. Checkley, K. (2000, May). The contemporary principal: New skills for a new age. Education Update, 43 (3) 1, 4-6, 8.

2. Daft, R. L. (2008). The Leadership experience (4 $4^{\text {th }}$ ed.). Mason, US: Thomson South Western.

3. Daft, R. L.,\&Marcic, D. (2006). Understanding management $\left(5^{\text {th }}\right.$ ed.). Mason, US: Thomson South Western.

4. Darling-Hammond, L. (2000). Teacher quality and student achievement: A review of state policy evidence. Education Policy Analysis Archives 8 (1). htpp://epa.asu.edu

5. Directorate of Quality Assurance and Standards (2006).Handbook on teachers' proficiency Course. Nairobi: Ministry of Education.

6. Edmonds, R. R. (1979). Effective schools for the urban poor.Educational Leadership, 37, 15-27.

7. Heider, F. (1958).The psychology of interpersonal relationship New York: John Wiley

8. Huczynski, A., and Buchanan, D. (2001).Organizational behaviour. An introductory text ( $4^{\text {th }} \mathrm{ed}$.). Edinburgh Gate, Essex: Pearson's Education Limited

9. Kelley, H. H. (1971). Attribution: Perceiving the causes of behaviour. New York: General Learning Press.

10. Kothari, C. R. (2008). Research methodology. ( $2^{\text {nd }}$ revised ed.). New Delhi: New Age International (P) Limited, Publishers. 
11. Leithwood, K. \&Jantzi, D. (2000). The effects of transformational leadership on organisational conditions and student engagement with school.Journal of Educational Administration Quarterly, 38 (2) 112129.

12. Mbiti, D. (2007).Foundations of administration. Nairobi: Oxford University Press.

13. Ministry of Education (2000).Handbook for inspection of institutions. Nairobi: Ministry of Education, Science and Technology.

14. Mugenda,G.A.(2008). Social science research.Theory and principles. Nairobi: Applied Research and Training Services.

15. National Centre for Education Statistics (NCES), (2000). Monitoring school quality: An Indicators Report- NCES 2001-030 Washington DC: US Department of Education, Office of Educational Research and Improvement.

16. Okoth, U.A. (2000). A study of the effect of leadership styles on performance in KCSE examination in Nairobi Province. Unpublished M.Ed Thesis. Nairobi: University of Nairobi.

17. Okoth, U.A. (2008). Instructional Leadership role of headteachersin the implementation of Environmental Education in Secondary Schools in Siaya District, Kenya. PhD thesis, Catholic University of Eastern Africa, Nairobi

18. Okumbe, J. A. (2007). Educational management.Theory and Practice Nairobi: University of Nairobi Press.

19. Prokopenko, J. (Ed) (1998). Management development. Geneva: International Labour Office (ILO).

20. Rowan, B., Correnti, R. and, Miller, R.S. (2002). What large-scale survey research tells us about teacher effects on student achievement: Insights from the prospects study of elementary schools. Teachers College Record, 104 (8), 1525-67.

21. Wafula, J.A. (2007). Teachers' perceptions on the role of Quality Assurance and Standards on quality of education in Nairobi Province.Unpublished M.Ed Project. Nairobi: University of Nairobi. 


\begin{tabular}{cccccc} 
Appendix & A: School (Head teachers') & Mean Score & \\
\hline $\begin{array}{c}\text { School } \\
\text { ID }\end{array}$ & $\begin{array}{c}\text { Instructional } \\
\text { Leadership } \\
\text { score }\end{array}$ & $\begin{array}{c}\text { Mean } \\
\text { Instructional } \\
\text { Leadership }\end{array}$ & $\begin{array}{c}\text { School } \\
\text { ID }\end{array}$ & $\begin{array}{c}\text { Instructional } \\
\text { Leadership } \\
\text { score }\end{array}$ & $\begin{array}{c}\text { Mean } \\
\text { Instructional } \\
\text { Leadership }\end{array}$ \\
\hline 1 & 81 & 4.5 & 16 & 48 & 2.6 \\
2 & 71 & 3.9 & 17 & 66 & 3.6 \\
3 & 72 & 4.0 & 18 & 73 & 4.0 \\
4 & 74 & 4.1 & 19 & 63 & 3.5 \\
5 & 66 & 3.6 & 20 & 62 & 3.4 \\
6 & 74 & 4.1 & 21 & 69 & 3.8 \\
7 & 55 & 3.0 & 22 & 71 & 3.9 \\
8 & 64 & 3.5 & 23 & 54 & 3.0 \\
9 & 56 & 3.1 & 24 & 69 & 3.8 \\
10 & 68 & 3.7 & 25 & 75 & 4.1 \\
11 & 70 & 3.9 & 26 & 64 & 3.5 \\
12 & 69 & 3.8 & 27 & 79 & 4.4 \\
13 & 70 & 3.9 & 28 & 82 & 4.5 \\
14 & 76 & 4.2 & 29 & 63 & 3.5 \\
15 & 69 & 3.8 & 30 & 67 & 3.7 \\
\hline
\end{tabular}

